\title{
FEED UTILISATION AND THE COMPOSITION OF ORGANS OF THREE STRAINS OF LAYING HENS FED CONSTANT ZINC AND VARYING LEVELS OF CALCIUM
}

\author{
By \\ OGUNMODEDE B.K. and IJAGBUJi, E.G. \\ University of Ibadan, Nigeria
}

\begin{abstract}
SUMMARY
At about $16 \mathrm{mg}$. zinc per $100 \mathrm{gm}$ of diet feed consumed by laying hens increased until a level of $2.0 \%$ dietary calcium. Increasing the dietary calcium to 2. $0 \%$ also stimulated more egg production. When less than $2.0 \%$ dietary calcium was fed more feed was required to produce a dozen eggs and the eggs were of small sizes. The egg shell strength and the bone calcium were improved when at least $\mathbf{2 . 0} \%$ dietary calcium was given to the laying hen. These results were correlated with tissue accumulation of zine thus establishing that for profitable egg production in the tropics $2.0 \%$ dietary calcium is required when $16 \mathrm{mg}$ zinc per 100 grains of feed is given.

\section{INTRODLCTION}

The relationship between calcium and phosphorus in the utilisation of foods and feeds has been well documented. However, dietary zinc has also been implicated with the physiological utilization of calcium. Thus Tucker and Salmon (1955) described the incidence of parakeratosis in pigs as a result of calcium - zinc imbalance. Also Morrison and Sarrett (1958) found that the addition of 0.5 to $1.0 \%$ calcium to chicks rations reduced weight gain while increasing the incidence and severity of hock disorder was normally associated with zinc deficiency. Since then interests have been stimulated in the utilisation of calcium and zinc by birds. Conflicting reports appear in the literature on this interrelationship. Turks, Sunde and Hokstra (1959) reported that chicks hatched from hens fed 9 p.p.m. zinc in a soybean protein diet were zinc deficient and that raising the calcium content of the ration up to $4 \%$ aggravated the deficiency. On the other hand, Turk (1965) observed that dietary zinc had no profound effect on the zinc Nigerian Journal of Animal Production 4 content of yolks and that dietary calcium did not alter the concentration of zinc in eggs.

Studies on tissue analysis also revealed similar conclusion. Lewis, Hoekstra and Grammer (1957), found that differences in zinc content of some tissues were statistically significant while little or no change in zinc concentration due to calcium intake occurred in others. As the high producing layers currently reared intensively need calcium for strong egg shells as well as bone formation, dietary calcium requirement of hens is constantly reviewed. Thus, Scott, Nesheim and Young (1969) proposed dietary levels of calcium at varying rates of egg production. This study seeks to establish the result of such variations on the composition of poultry products from three strains of laying hens available in Nigeria.

\section{MATERIALS AND METHODS}

An experimental design using the randomised block was applied to five treatments with three replicates. A total of 210 layers consisting of equal numbers of Harco; Amo Kathline and White Plymouth Rock birds that had been in production for between three and five weeks were selected. The birds were kept in battery cages with feed supplied ad libitum as shown in Table 1. Water was available to the birds at all times. The calcium content of the rations were varied by including oyster shell at varying levels in the diets. After 10 days of preliminary period, records of feed intake were made for the next 22 weeks.

The feeds were analysed for calcium and zine with an atomic absorption spec- 
trophotometre after a wet digestion. Phosphorus was determined by the phospho-vanadomolybdate method of Kitson and Mellon (1944) while the crude protein in the feeds was determined by the A.O.A.C. method (1970).

Egg production was recorded and the feed/dozen eggs was calculated. The egg weights were obtained daily and the egg shell weight as well as the egg shell thickness were determined by the method of Carter (1974). The calcium content of the egg shell was also obtained by atomic absorption spectrophotometry.

After 22 weeks of experimentation, 10 birds from each of the treatments were killed and the zinc concentration of the oviduct, kidney and egg yolk.were determined while the femur calcium was estimated with the atomic absorption spectrophotometre after wet digestion. The tissues were analysed as they aresensitive indicator of zinc status. The results were analysed statistically by the analysis of variance and the Duncan's muliple' range test.

TABLE 1

1 Percentage Composition of Experimental Rations

\begin{tabular}{|c|c|c|c|c|c|c|c|c|c|}
\hline Components & $\ldots$ & $\ldots$ & $\ldots$ & $\ldots$ & 1 & 2 & 3 & 4 & 5 \\
\hline Maize & $\ldots$ & $\ldots$ & $\ldots$ & $\ldots$ & 66.0 & 65.6 & 65.2 & 64.8 & 64.4 \\
\hline Groundnut ca & $\mathrm{ke}$ & $\ldots$ & ... & $\ldots$ & 20.0 & 20.0 & 20.0 & 20.0 & 20.0 \\
\hline Rice bran & $\ldots$ & $\ldots$ & $\ldots$ & $\ldots$ & 3.0 & 3.0 & 3.0 & 3.0 & 3.0 \\
\hline Palm Oil & $\ldots$ & $\ldots$ & $\ldots$ & $\ldots$ & 3.0 & 3.0 & 3.0 & 3.0 & 3.0 \\
\hline Yeast ... & $\ldots$ & $\ldots$ & $\ldots$ & $\ldots$ & 3.0 & 3.0 & 3.0 & 3.0 & 3.0 \\
\hline DCP $\ldots$ & $\ldots$ & $\ldots$ & $\ldots$ & $\ldots$ & 4.5 & 4.5 & 4.5 & 4.5 & 4.5 \\
\hline Salt ... & $\ldots$ & $\ldots$ & $\ldots$ & $\ldots$ & 0.4 & 0.4 & 0.4 & 0.4 & 0.4 \\
\hline Minerals and & Vital & $15(\mathrm{Ad}$ & it. fo & ers) & 0.5 & 0.5 & 0.5 & 0.5 & 0.5 \\
\hline Methionine & $\ldots$ & $\ldots$ & $\ldots$ & $\ldots$ & 0.5 & 0.5 & 0.5 & 0.5 & 0.5 \\
\hline Oyster shell & $\ldots$ & $\ldots$ & $\ldots$ & $\ldots$ & - & 0.4 & 0.8 & 1.2 & 1.6 \\
\hline
\end{tabular}

\section{RESULTS AND DISCCSSIONS}

Results of feed analysis and consumption in Table 2 show that the dry matter the energy and protein in the feed were relatively constant and that the calcium level varied at constant dietary zinc level. Feed consumption values showed that for the Harco and Amo Kathline birds, intake increased from low calcium level of $1.7 \%$ to a level of $2.1 \%$ and a gradual decline in consumption accompanied raising dietary calcium to $2.31 \%$. The analysis of variance showed significant differences in feed intake as being due to both the breed and the rations. Generally the White Rock hens tended to consume more fod than the other two strains of layers.

TABLE 2

Feed Data and Consumption

\begin{tabular}{|c|c|c|c|c|c|c|c|c|}
\hline \multicolumn{9}{|c|}{ Ration Numbers } \\
\hline & & & & 1 & 2 & 3 & 4 & 5 \\
\hline Dry matter $(\%)$ & $\ldots$ & $\ldots$ & $\cdots$ & 83.0 & 82.0 & 82.0 & 81.6 & 81.4 \\
\hline Crude protein $(\%)$ & . & $\ldots$ & $\ldots$ & 17.5 & 17.3 & 17.5 & 17.4 & 17.4 \\
\hline \multicolumn{3}{|c|}{ Metabolizable energy (Kcal/kg.) } & $\ldots$ & 2565.3 & 2551.6 & 2537.9 & 2524.1 & 2510.2 \\
\hline Calcium $(\%) \ldots$ & $\ldots$ & $\ldots$ & $\ldots$ & 1.7 & 1.85 & 2.0 & 2.16 & 2.31 \\
\hline Zinc (mg/100g) & $\ldots$ & $\ldots$ & $\ldots$ & 16.0 & 16.0 & 15 & 16 & 15 \\
\hline Phosphorus $(\%)$ & $\cdots$ & $\ldots$ & $\ldots$ & 1.1 & 1.2 & 1.3 & 1.1 & 1.3 \\
\hline \multicolumn{9}{|c|}{ Av. daily dry matter intake (gms): } \\
\hline Harco & $\cdots$ & $\ldots$ & $\cdots$ & $66 \mathrm{~b}$ & $55 \mathrm{a}$ & $73 b$ & $70 \mathrm{ab}$ & $68 a$ \\
\hline White Rock ... & $\ldots$ & $\ldots$ & $\ldots$ & $76 \mathrm{c}$ & $73 b$ & $79 b$ & $75 \mathrm{~b}$ & $76 \mathrm{~b}$ \\
\hline Amo $\ldots \quad \ldots$ & $\cdots$ & $\ldots$ & $\ldots$ & $59 a$ & $60 \mathrm{a}$ & $65 \mathrm{a}$ & $69 \mathrm{ab}$ & $63 a$ \\
\hline
\end{tabular}

Values denoted by the same alphabet in a vertical line are statistically insignificant at $5 \%$ level. 


\section{Zn/Ca RATIO IN LAYERS MASH}

The different measurements taken on the eggs produced ate shown in Table 3. The birds fed ration 1 that had no additional source of calcium produced the lowest number of eggs. This was particularly noticed in both the Harco and Amo Kathline birds. When the result for birds in group with $1.84 \%$ dietary calcium was considered an improvement especially for Amo Kathline and the White Rock was observed. Increasing the dietary calcium to 2.0 and $2.16 \%$ in rations 3 and 4 stimulated more egg production. A look at both Tables 2 aitd 3 revealed that at low detary calcium level feed consumption was low and total egg production was also low especially in the Amo birds. How zver, increascd egg production accompanied increased feed consumption. Also at $2.31 \%$ dietary calcium feed consumption and egg production were not improved over $2.16^{\%} \%$ dietary calcium.
This observation agrees with those of Nevalainen (1969); Roland, Sloan and Harms (1972), that high supplementation of dietary calcium tends to depress feed intake and that dietary $2.5 \%$ calcium stimulated more feed consumption in hens than $3.5 \%$.

Feed efficiency was measured in terms of feed required to produce a dozen egg. Birds on low levels of dietary calcium especially those in group 1 had high feed/ dozen egg values thus indicating a low feed efficiency in this regard. It is conceivable that the hens had to withdraw calcium from more feed for deposition in the egg as the calcium level of the feed was low. However, since feed consumption was low, the egg production was correspondingly low and inefficient. Higher levels of dietary calcium at constant zinc level of $16 \mathrm{mg} / 100 \mathrm{gm}$ of feed improved feed efficiency for egg production.

TABif 3

lgg Introduction and Quality of Eggs From the Experimental Birds

\begin{tabular}{|c|c|c|c|c|c|c|}
\hline & \multirow{2}{*}{ Strain* } & \multirow[b]{2}{*}{$I$} & \multicolumn{2}{|c|}{ Treatments } & \multirow[b]{2}{*}{4} & \multirow[b]{2}{*}{5} \\
\hline & & & 2 & 3 . & & \\
\hline Av. egg production pe bird for & or 22 weeksH & $62 \mathrm{a}$ & $65 \mathrm{a}$ & $88 \mathrm{~b}$ & $106 \mathrm{c}$ & $87 b$ \\
\hline & w & $77 a$ & $92 \mathrm{t}$ & $96 \mathrm{~b}$ & $99 b c$ & $107 \mathrm{~b}$ \\
\hline & A & $40 \mathrm{a}$ & $85 h$ & $90 \mathrm{bc}$ & $94 \mathrm{c}$ & $79 \mathrm{~b}$ \\
\hline \multirow[t]{3}{*}{ Feed/dozen eg!r; $; k g)$} & $\ldots \mathrm{H}$ & $2.64 \mathrm{a}$ & $2.39 t$ & $1.67 \mathrm{c}$ & $1.62 \mathrm{c}$ & $1.22 \mathrm{~d}$ \\
\hline & W & $2.32 \mathrm{a}$ & $1.94 \mathrm{t}$ & $1.64 \mathrm{c}$ & $1.66 \mathrm{c}$ & $1.32 \mathrm{~d}$ \\
\hline & $A$ & $3.27 \mathrm{a}$ & 1.63t: & $1.80 \%$ & $1.62 \mathrm{~b}$ & $1.50 \mathrm{~d}$ \\
\hline \multirow[t]{3}{*}{ Av. egg weigh (gms) } & $\ldots \mathrm{H}$ & 57.97 & 58.40 & 58.60 & 56.65 & 61.71 \\
\hline & W & 52.19 & 55.94 & 55.71 & 55.62 & 54.58 \\
\hline & A & 50.93 & 56.89 & 60.46 & 63.26 & 58.73 \\
\hline \multirow[t]{3}{*}{ Av. egg shell wight (gms) } & $\ldots \mathrm{H}$ & $4.29 \mathrm{a}$ & $4.76 \mathrm{~b}$ & $5.04 \mathrm{c}$ & $4.94 \mathrm{c}$ & $5.12 \mathrm{c}$ \\
\hline & W & $4.70 \mathrm{a}$ & $4.53 \mathrm{~h}$ & $5.33 \mathrm{~b}$ & $5.35 \mathrm{~b}$ & $5.36 \mathrm{~b}$ \\
\hline & A & $3.85 a$ & $5.00 \mathrm{~b}$ & $5.54 \mathrm{c}$ & $5.43 \mathrm{bc}$ & $5.35 b$ \\
\hline \multirow[t]{3}{*}{ Mean egg shell thickn's (mm). . } & $\ldots H$ & $.276 \mathrm{a}$ & $.312 \mathrm{t}$ & $.315 \mathrm{~b}$ & $.328 \mathrm{c}$ & $.348 \mathrm{~d}$ \\
\hline & W & $.284 a$ & $.314 \mathrm{k}$ & $.370 \mathrm{c}$ & $.363 \mathrm{c}$ & $.378 \mathrm{c}$ \\
\hline & A & $.265 \mathrm{a}$ & $.326 \mathrm{~b}$ & $.345 \mathrm{c}$ & $.335 \mathrm{c}$ & $.343 c$ \\
\hline
\end{tabular}

${ }^{*} \mathrm{H}=$ Harco, $\quad W=W$ hite Rock and $A=$ Amo Kathline.

The results for the egg weights showed that lighter eggs were produced when $1.7 \%$ calcium and $16 \mathrm{mg} / 100 \mathrm{gm}$ of zinc were fed. The difference between 1.85 , $2.0,2.16$ and 2.31 calcium at the same level of zinc used in the experiment were not statistically significant. Also eggs from the Amo Katheline and the Harco birds tended to be heavier than those from the White Plymouth Rock, although the differences were statistically insignificant.

The study of average egg shell weight showed that it increased until $2.0 \%$ calcium was present in the ration. The highest value of $5.54 \mathrm{gms}$ was obtained for the Amo birds on ration $3(2.0 \%$ calcium while the lowest value 3.85 was also for the Amo birds on $1.7 \%$ calcium diet ration 1). Thus differences existed as a result of both breed and dietary calcium 


\section{$O G U N M O D E D E \& I J A G B U J I$}

at $16 \mathrm{mg}$ zinc per $100 \mathrm{gm}$ diet. The Duncan's multiple range test revealed that rations 3,5 and 2 were significantly different from ration 1 but no differences were observed between rations 3,4 and 5 . This observation agreed with that of Bragg, Floyd and Stephenson (1970) that dietary calcium restriction result in reduced egg shell weight.

Measurement of the egg shell thickness showed that increasing the levels of dietary calcium at the level of zinc used resulted in improvement of shell thickness. Statistically significant differences were obtained between the rations and the breeds while the Duncan's multiple range test revealed that calcium levels of $2.0,2.16$ and $2.31 \%$ aided better egg shell thickness than 1.7 and $1.85 \%$ dietary calcium. Also the muitiple range tesi showed significant differences between White Rock and the Harco birds especially at $2.0 \%$ calcium and above.

Table 4 shows the amount of calcium deposited in the egg shell and in the femur. High dietary calcium increased the egg shell content of the mineral and birds given $1.7 \mathrm{gm}$ of calcium had the least amount of the mineral in the shell. The analysis of variance showed differences between the Rations and from the Duncan's multiple range tes! it was shown that dietary calcium levels of $2.0,2.16$ and $2.31 \%$ were significantly different from 1.7 and $1.85 \%$. Furthermort, ic was clear that optimum dietary calciurn needed by the laying hen would be about $2.0 \%$ and that higher levels do not improve the shell quality further, indeed wastage would ensue.

The femurs of birds on calcium supplemented diets had lower misture content $(25-29 \%)$ than those of the unsupplemented group. The levelswt calcum in the bone can be explained using the observation of Mueller, Schraer and Schraer (1964) that depletion of the femur calcium accompanies deficiency of dietary calcium in the laying hen. Thus the more adequate the ration is with respect to calcium the higher, within limits the calcium content of the femur. This phenomenon could be observed in the experimental groups of birds and it is thus confirmed that dietary calcium supplies only part of the calcitim needed for egg shell as obscived by Driggers, Shirley, Davis and Mehrhoff, (1951).

TABI:F: 4

Calcium Deposition in the Egg Shell and Femur (gms)

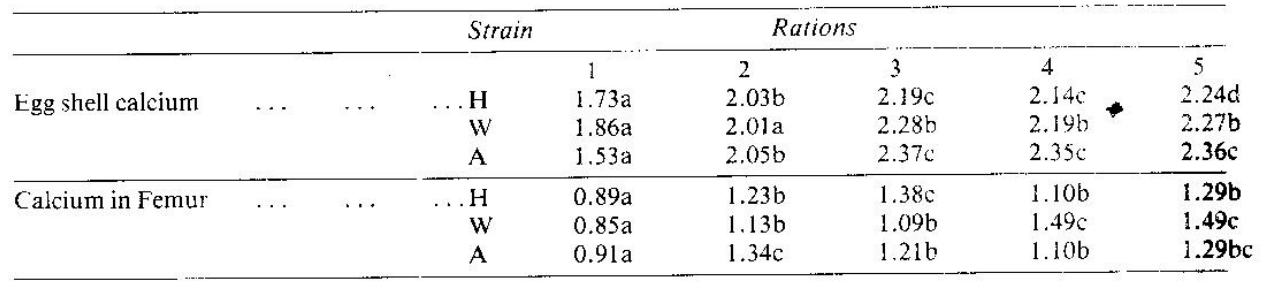

The amount of zinc present in selected organs of the experimental birds are shown in Table 5 . The liver zinc concentration was expressed as a fraction of the fresh weight of the liver. The differences between the calcium levels and zinc accumulation in the liver were not significant but differences occurred as a result of the strain of the laying hen. In most treatments, the Amo Kathline birds deposited more zinc in the liver than the White Rock which also had more liver zinc than the Harco birds. This finding did not agree with those of Lewis, Hoekstra and Grammer (1957) that increasing dietary calcium depleted liver calcium. The contrast could be due to the low level of zinc $(3.5-7.0 \mathrm{mg} / 100 \mathrm{~g}$ sample) fed by earlier workers when increasing dietary zinc in the liver of zinc 


\section{Zn/Ca RATIO IN LAYERS MASH}

deficient birds.

In the kidneys, increasing levels of dietary calcium resulted in reduction of zinc accumulation. The differences were significant for the rations regardless of the strain of laying birds. This was similar to the result of Bronner and Thomson (1961) who observed that the kidney resorbs about $98 \%$ of the filtered calcium but excretes the zinc more than the liver does. Like the kidney, inverse relationship existed between dietary calcium and the total zinc of the oviduct. There was no breed effect on these differences. Inverse relationship also existed between the dietary calcium level and the egg yolk zinc especially above $2.0 \%$ dietary calcium. This agreed with the observation of Kienholz (1961) that dietary calcium had no profound effect on the zinc content of the egg yolk when adequate calcium was fed but that high levels of dietary calcium aided appreciable decline of zinc in the egg yolk.

TABLE 5

Zinc in Organs of Laying Hens Fed Graded Calcium

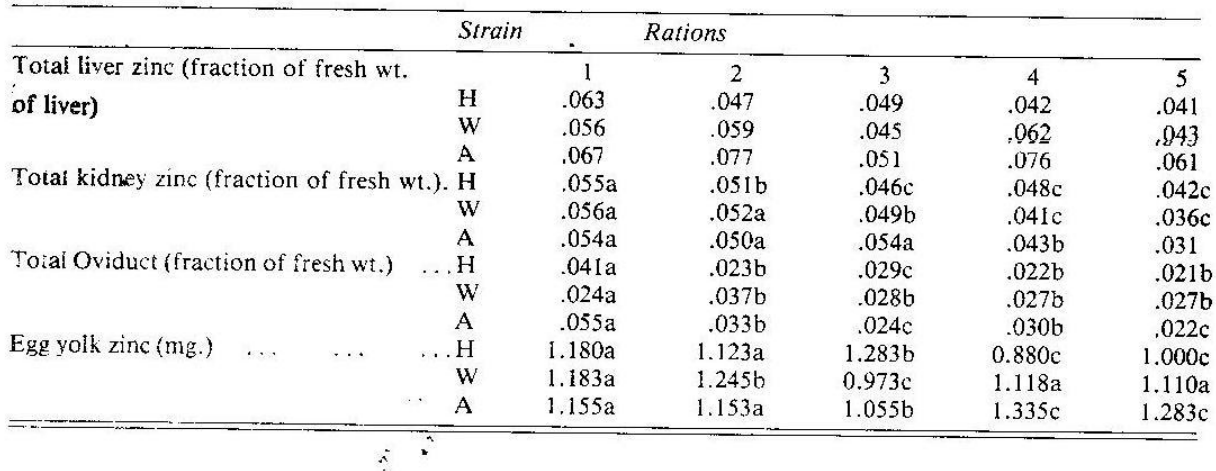

\section{REFERENCES}

A.O.A.C. 1970 Methods of Analysis. Association of Official Analytical Chemists. Washington D.C.

BragG, D.B. Floyd, J. and STEPHENSON,E.L.1970. Factors affecting the transfer of calcium from the hen's diet to the egg shell. Poult. Sci. 50; $167-173$.

BRONNER, F. and THOMSON, D. 1961. Calcium met-abolism in the kidney: In Mineral Meta-bolism. Vol. 2A edited by Comar and Bronner: 452 .

CARTER, T.C. 1974. The hen's egg: Estimation of shell superficial area and egg shell volume. $\mathrm{Br}$. Poult, Sci. 13(5); 507-514.
Driggers, J.C., Shirley, R.L., Davis, G.K. and MEHRHOFF, N.R. 1951. The transference of radioactive calcium and phosphorus from hen to chick. Poult. Sci. 30; 199-204.

KITSON; R.E. and MELlON, M.C. 1944. The determination of phosphorus. Ind. Eng. Chem. (Anal. Ed.) 16; 397-399.

LEWIS, P.K., HoEkstra, W.G. and GRAMMER, R.H.1957. Restricted calcium feeding versus zinc supplementation for the control of parakeratosis of swine. J. Anim. Sci. 16; $578-588$.

Morrison, A.B. and SARrett, H.P. 1958. Studieson zinc deficiency in the chick. J. Nutr. 65; 267-280. 
MUeleer, W:J., Schraer, R, and SCHRAER, H. 1964. Calcium metabolism and skeletal dynamics of laying pullets. J. Nutr. 84; 20-33.

Nevalainen, T.J. 1969. Effect of calcium deficiency on reproductive organs of hens. Poult. Sci. 48; $653-659$.

Roland, D.A., SADAN, D.R. and HARMS,R.H.1972. Calcium metabolism in laying hens. Poult. Sci. 51; 1388-1391.

Scott, M.L., Nesheim, M.C. and YOUNG,R.J.1969. Calcium re- quirements of laying hens. Nutrition of the Chicken. M.L. Scott and Associates. Ithaca, N.Y. 273.

TUCKER, H.F. and SALMON, W.D. 1955. Parakeratosis or zinc deficiency in pigs. Proc. Soc. Exptl. Biol. Med. 88; 613-622.

TURK, D.E., SUNDE, M.L. and HOF.KSTRA,W.G.1959. Zine defiency experiments with poultry. Poult. Sci. $38 ; 1256$.

TURK, D.E. 1965. Effect of diet on the tissue zincdistribution and reproduction in fowl. Poult. Sci. 44; $122-126$. 